\title{
The Link between Default Risk and Macroeconomy in Tunisia: Cointegration Approach
}

\author{
Amel Ben Youssef ${ }^{1}$ \\ ${ }^{1}$ Faculty of Economic sciences and Management of Tunisia, FSEGT, El Manar, Tunis, Tunisia \\ Correspondence: Amel Ben Youssef, Faculty of Economic Sciences and Management of Tunisia, FSEGT, \\ B.P.248 El Manar II 2092 Tunis, Tunisia. Tel: 216-98-544-603. E-mail: amoulaby@yahoo.fr
}

Received: December 25, 2013

Accepted: January 21, 2014

Online Published: March 25, 2014

doi:10.5539/ijef.v6n4p257

URL: http://dx.doi.org/10.5539/ijef.v6n4p257

\begin{abstract}
This paper examines the long-term and short-term causal relationships between default risk and macroeconomic factors in Tunisia, by studying the time series stochastic behavior and cointegration in a set of Non-Performing Loans rate and macroeconomic variables. We consider the linkage in the global economy and in five sectors. This approach requires the construction of macroeconomic credit model providing the framework to perform assessing causal relationship between variable pairs to improve the capture of the relation between macroeconomic variables and probabilities of default for the main Tunisian sectors and which macroeconomic variables are important for each sector and the global economy.
\end{abstract}

Keywords: default, credit risk, multivariate, cointegration, macroeconomy

\section{Introduction}

The recent global financial crisis motivates the regulatory authorities to rethink about the credit policy. Indeed, the global credit boom has been the main factor of the financial crisis. Then, the credit risk management tools have been inefficient in maintaining the financial stability. Many researches are made in modeling integration of credit and financial areas. But, the financial stability can't be managed by a model or industry, because it's more complex than a simple mathematical operation. The key motivation for this paper is to improve our understanding of the link between financial stability and economy as a tool for macro-prudential regulation in the Tunisian financial system

In the last decade, Macroeconomic credit risk models become a very useful tool for central banks for managing the banking system and the financial stability. Regulators want to know the likely default rate in the near future. Macroeconomic indices can indicate the future risk by modeling this relationship. These models help central bank to estimate the impact of introducing a prospective monetary policy or of macroeconomic shocks. But, this modeling is limited by the data unavailability in the less developed economies.

As the aggregate default rate is a good measure of the financial stance of the economy. Then, macroeconomic models can help with understanding the influence of macroeconomic changes on the default events.

The target of this paper was investigation of the possible approaches of default rate macro modeling in literature and application of a suitable model for the Tunisian economy. For this aim, we consider the possible long run relation for the default rate as reflected on its own logit transformation and the other macroeconomic variables in Tunisia by using cointegration analysis and precisely (Johansen, 1988) methodology for the aggregate economy and also for five specific sectors (agriculture, manufacturing, construction, service, tourism).

The key contribution of the paper lies in developing macroeconomic credit risk models for default rate prediction suitable to a transitional economy with insufficient capital market such the Tunisian economy and able to detect the macro-financial vulnerabilities for a financial stability purpose. Also, the paper specificity is to add evidences that some macroeconomic variables which have been found to have a great influence on credit risk in literatures are cointegrated with the default rate in various economy sectors. In this way, we could retrace some of the earlier empirical evidence on the relation between credit risk and the macro-economy.

Our results open up a new possibility for making default probabilities dependent on the state of the economy. The paper mainly asserts the significance of cointegrating relationships at each sector chosen. Relations with specific default rates show the influence of the interest rate in each sector credit risk and the specific 
indebtedness is significant in certain sectors and in the global model. The oil price is also influencing in the majority of models excepting the agriculture model.

This article follows up the other type of credit models based on macroeconomic credit risk modeling but few papers focus on developing these sort of macroeconomic models in a cointegrating manner.

Three main approaches can be distinguished within macroeconomic credit risk models. The first, traditional and frequently used in emerging economies where the capital market is insufficiently advanced, it is based on finding an empirical relationship between a dependent variable representing default rate and key macroeconomic indicators. The second approach is derived from the Merton structural model, the firm's default is related to a fall of borrower's return assets under some threshold Jakubik (2007). The third method for modeling credit risk is to apply reduced form models that lie on the assumption that the default is a random event occurring by surprise at any time and it uses data on the corporate bonds and shares market prices as inputs. The reduced form approach has been used for credit risk by Jarrow, Lando and Turnbull (1995; 1997); Lando and Skødeberg (2002); Duffie, Saita and Wang (2007); Koopman et al. (2008). The third model type can't be used for credit risk analysis in Tunisia, given its underdeveloped capital market.

We link this paper to aggregate study of the risk literature. Wilson (1997a; 1997b) establishes the originally principle of McKinsey's portfolio credit risk model (Credit Portfolio view); the default and migration probabilities are not independent of the business cycle. Nickell et al. (2000) investigate the dependence of rating transition probabilities on the state of the economy. Diebold, Kronimus, Schagen and Schuermann (2002) found that default intensities differ across different economic regimes. Allen and Saunders (2004) highlight the treatment of systemic risk factors in some credit risk models. Virolainen (2004) used the wilson's framework to find a significant relationship between corporate sector default rates and macroeconomic factors in Finland. Boss (2002) and Boss et al. (2006) try to improve the detection of the relation between macroeconomic variables and probabilities of default for the Austrian sectors. Pesaran et al. (2006) develop a global macroeconometric model allowing for the interdependencies between national and international factors in a Merton-type credit risk to assess the impact of macroeconomic variables on firm's probabilities of default. Koopman and Lucas (2005) model jointly the business failure of US firms and the macro-economic developments by a multivariate unobserved components approach to outline the dynamic link between credit risk factors and the real economy. Carling et al. (2007) combine the firm-specific variables and the macroeconomic conditions to better capture the appropriate default risk in Sweden. Jakubik (2007) extends Virolainen empirical default model to a latent factor model estimated for the aggregate economy to develop a macroeconomic credit model for the Czech economy. Duffie et al. (2007) develop a model for the term structure of credit risk as a function of a small number of structural and macro factors to a forecasting aim. Jakubik and Schmieder (2008) compare the macroeconomic determinants of default in Czech republic a transitionary country and Germany a developing country for corporate and household sectors of both countries by employing different specifications. Ali and Daly (2010) also compare between the importance of macroeconomic variables by two macroeconomic credit models applied respectively on Australia which is relatively immune from the recent global crisis and the USA the most affected by the GFC to highlight the financial system vulnerability in each two former countries. Tabak et al. (2011) show that macroeconomic variables effects on default probabilities in Brazil can be constructed in an economic sector system (Minimum Spanning Tree )to identify connections between sector's default probabilities and therefore to optimize the credit risk management. Figlewski et al. (2012) confirm that the explanatory power of a reduced form credit risk model significantly increase when adding macroeconomic factors into a specification with ratings-related variables explanatory power.

Meanwhile, few papers focus on a mutual relationship between macroeconomic conditions and credit risk and on catching long-run relationships between the variables studied as well as short-run fluctuations around these relationships. The mutual relationship between the macro-economic factors and credit risk is specially applied in practice in the CreditPortfolioView model and his empirical evidence is based on (Wilson, 1997a, b).

Moreover, VAR can be applied for nonstatonarity time series if cointegration exists. It's a vector error correction model (VECM) which can detect long-run relationships between the variables studied as well as short-run fluctuations around these relationships. It also catches short-run fluctuations around these relationships and allows considering shared trends and feedback between series.

Many studies generally investigate the macroeconomic factors that induce credit risk. Borio and Lowe (2002) argue that excessive credit growth often precedes banking crisis as it is reflected by credit standards deterioration. Similar results can be found in Demirgüç-Kunt and Detragiache (2005) and Davis and Karim (2008). Salas and Saurina (2002) find that GDP growth rate is a macroeconomic factor that explains credit risk in Spanish banks in 
addition to individual bank level variables. Furthermore, the study by Dimitrios et al. (2011) strongly suggests that macroeconomic variables, specifically the real GDP growth rate, the unemployment rate and the lending rates have a strong effect on the level of NPLs in the Greek financial sector. Fofack (2005) also explores the leading causes of nonperforming loans in Sub-Saharan Africa using causality and pseudo-panel models. He highlights a strong causality between non-performing loans and economic growth, inflation, real exchange rate appreciation, the real interest rate as macroeconomic variables.

The remainder of this paper is organized as follows. I explain the model choice and estimation technique in Section 2. Then, I discuss the components of the model, report results for aggregate measure of credit risk in Tunisia and, in addition, according to economic sectors and discuss their policy implications in Section 3. I conclude in Section 4.

\section{Method}

The procedures used for stationary testing, cointegration testing, and the ECM model estimation are described in detail in this section.

For the aim testing that dependent variable, default rate, defined as non-performing loans rate, is sensitive to macroeconomic variables in a mutual manner, we impose in a Wilson's model feedback effects between default rates and macroeconomic variables. Then, the relationships between default rates and macroeconomic factors are estimated jointly in a multivariate framework, in the manner that each variable may depend on its own lags and on each of the others variables. VAR is used to investigate the evolution and interdependencies between multiple time series time series. But VAR can additionally be applied for nonstatonarity time series if cointegration exists. It's a vector error correction model (VECM) which can detect long-run relationships between the variables studied as well as short-run fluctuations around these relationships.

Within this study, we refer to Wilson's specifications (1997a, 1997b) in the Credit Portfolio View. It consists in:

i. An empirical model representing the default rate of a given sector by a logistic function:

$$
p_{t}=\frac{1}{1+e^{-y_{t}}}(\text { Note } 1)
$$

Where $y_{t}$ is the sector- specific macroeconomic index at time $t$ and calculated according to the following linear relation to $\mathrm{n}$ macroeconomic factors:

$$
y_{t}=\beta_{0}+\beta_{1} x_{1, t}+\beta_{2} x_{2, t}+\ldots+\beta_{n} x_{n, t}+u_{t}
$$

Where $x_{i, t}(i=1, \ldots, n)$ denote the macroeconomic variables and $\beta_{i}(i=1, \ldots, n)$ stand for the parameters to be estimated. These parameters determine the impact direction and extent that have the factors on the index. They are estimated by the former linear regression where errors terms $u_{t}$ are assumed to be independent, normally distributed $\varepsilon_{\mathrm{t}} \sim \mathrm{N}\left(0, \sigma_{\varepsilon}\right)$.

ii. Another part of the equation system in Wilson's original specification is about the dynamics of the $n$ macroeconomic variables which follow an autoregressive (AR) process of order q generalized as the following specification:

$$
x_{i, t}=\rho_{i, 0}+\sum_{j=1}^{q} \rho_{i, j} x_{i, t-j}+v_{i, t} \text { for } \mathrm{i}=1, \ldots, \mathrm{n}
$$

Where $\rho_{i, j}$, for $\mathrm{j}=1, \ldots, \mathrm{q}$ and $\mathrm{i}=1, \ldots, \mathrm{n}$, are unknown coefficients to be estimated; for each $\mathrm{i}, v_{i, t}$ is an i.i.d error term.

Equations (i) and (ii) define the joint evolution of the economic performance, the associated default rates, and their error terms.

Once the coefficients $\beta_{i}(i=1, \ldots n)$ are estimated, we can estimate the default probabilities on the basis of estimated macroeconomic index. Nevertheless, $y_{t}$ is not stationary. Thus, the macroeconomic index first difference is used in the estimation $\left(\Delta y_{t}=y_{t}-y_{t-1}\right)$. It results that:

$$
\hat{p}_{t}=\frac{1}{1+e^{-\left(\hat{y}_{t-1}+\Delta \hat{y}_{t}\right)}}
$$

But this equation system has weakness when equation (ii) doesn't include current and past values of $y_{t}$, that's why, we opt to a multivariate framework allowing for interdependence between macroeconomic factors and the default rate. If macroeconomic factors are nonstationary, a linear combination of them might be stationary, which is interpreted as a long-run equilibrium relationship called the cointegrating equation.

In the case of cointegration absence, Stationary processes can be analyzed using a simple VAR model. A $\mathrm{n}$-variable VAR model of order $\mathrm{p}$ can be written as: 


$$
Z_{t}=\mu+\sum_{i=1}^{p} \Gamma_{i} Z_{t-i}+\varepsilon_{t}
$$

where $Z$ is an $n \times 1$ vector of macroeconomic factors and macroeconomic index series at time $\mathrm{t}, \Gamma_{i}$ is a $(\mathrm{n} \times \mathrm{m})$ matrix of coefficients relating series changes at lagged i period to current changes in series, $\mu$ is a $(\mathrm{n} \times 1)$ vector of constants, and $\varepsilon_{t}$ is a $(\mathrm{n} \times 1)$ is a zero mean white noise vector process. According to this former equation, each of the $\mathrm{n}$ variables is a function of $\mathrm{n}$ lags of all variables, including itself, a constant and a contemporaneous error term.

If the variables in the vector $\mathrm{Z}$, are integrated of order $\mathrm{r}$, and are also cointegrated, then the VAR model in equation (4) is referred to as VEC at cointegration restriction has to be included. The VEC representation following Johansen and Juselius is the standard VAR in the first differences of $Z t$, augmented by the error correction terms $\alpha \beta^{\prime} Z_{t-1}$ :

$$
\Delta Z_{t}=\mu+\sum_{i=1}^{k-1} \Gamma_{i} \Delta Z_{t-i}+\alpha \beta^{\prime} Z_{t-1}+\varepsilon_{t}
$$

where,

$\Gamma$ are $(\mathrm{n} \times \mathrm{m})$ coefficient matrices $(\mathrm{i}=1,2, \ldots, \mathrm{k})$,

$\alpha, \beta$ are $(\mathrm{n} \times \mathrm{r})$ matrices,

where $r$ the number of cointegration relationships.

Matrix $\beta$ is the cointegrating matrix of $\mathrm{r}$ cointegrating vectors, $\beta_{1} \beta_{2}, \ldots, \beta_{i}$. The $\beta$ vectors represent estimates of the long-run cointegrating relationship between the variables in the system. The error correction terms, $\beta^{\prime} \mathrm{Zt}-1$, are the mean reverting weighted sums of cointegrating vectors. Matrix $\alpha$ includes information on the speed of adjustment, known as the adjustment parameters in the vector error correction model.

According to Johansen (1988) and Johansen and Juselius (1990), testing the hypothesis on $\beta$ can provide information on long-run structure, while testing the hypothesis on $\alpha$ and $\Gamma_{i}$ can identify the short-run relationships. The Johansen-Juselius (JJ) approach provides maximum likelihood estimates of $\alpha$ and $\beta^{\prime}$ through two statistics, the trace ( $\lambda$ trace) and maximum eigenvalue $(\lambda \max )$ test, that allow the number of cointegrating vectors determination.

We modeled and estimated economic sector-specific default rates to obtain a better default rate estimation than those obtained with an aggregate model.

\section{Results}

\subsection{Data}

The study employs quarterly time series data for the following factors (for 11 years, 2000Q1 to 2010 Q4):

- The Default rate which is based on Non-Performing Loans/total loans. The quarterly default data is available for the global economy and for the following five sectors: (1) agriculture (AGR), (2) manufacturing (MAN), (3) construction (CON), (4) service (SERV) and (5) tourism (TOUR);

- Gross Domestic Product for (global economy, agriculture, estate, service, industry and tourism);

- Interest rate

- Debt-to-GDP ratio for (global economy, agriculture, estate, service, industry and tourism);

- Stock Market index (tunix);

- Brent price;

- Inflation rate;

- Real Effective Exchange rate;

- Unemployment rate;

- Money supply (M1).

We consider many macroeconomic indicators that should have a significant impact on the default rate were selected.

The choice of macroeconomic variables used in the study was motivated by Boss (2002), Gray and Walsh (2008), and Kalirai and Scheicher (2002). The data were provided by the Tunisian Central Bank (BCT) and National Statistics Institute (INS). Summary statistics of these variables are given in Table 1.

-GDP: we consider the real GDP in the Tunisian economy. It describes the economic activity health. Then lower GDP growth means a lower activity in firms, increasing probability that firms reach the default stage. Therefore, 
the expected sign between default rate and real GDP is negative.

-The reason for incorporating the indebtedness ratio debt-to-GDP-ratio as a variable is obvious. Indeed, the vulnerability of an economic sector depend on the extent of its indebtedness, it directly affects the burden of the debt. We use for each specific economic sector its relative corporate debt to GDP ratio. The hypothesis here is a positive relationship between the indebtedness in a sector and its relative level of default.

- We consider stock market index relevant in our model because it's a leading indicator for economic activity. If the Tunindex declines, the incentive to continue servicing the debt will weaken. Then, we supposed a negative relation between default rate and Tunindex in each model as the Merton's theory which predicts that the probability of default is negatively related to the stock market return.

- We hypothesize that greater the inflation, less is the default probabilities. But the negative impact of inflation on firm's default rate is less evident: inflation tends to improve the financial situation of debtors in the short run and ceteris paribus leads to a decrease of companies default rate (Jakubik, 2008).

-As Tunisia is an importer of crude oil, our expectation is that a rise in this commodity price should increase the default probabilities in Tunisian economic sectors. Indeed, energy prices affect the price of most of the products used in the economic system.

-Interest rate should have positive impact on default probabilities; an increase in interest rates result in a prompt increase in the funding rates of the corporate and thus to a worsening of firm's ability to meet their financial obligation due to more expensive financial resources.

- We supposed that a stronger real effective exchange rate of the domestic currency should mean a greater default probability.

- Unemployment rate is expected to have a positive relationship with corporate default rate.

- An inflation targeting approach to monetary policy would cause the borrower's creditworthiness deterioration. Then, we suppose that an increase of money supply has a positive effect on default probability.

The quarterly development of the Tunisian non performing loans in the time period 2000:1-2010:4 is displayed globally (Figure 1) and per sector (Figure 2). It clearly shows the decrease of the overall corporate NPL-based default rate from a very high level of around $23,6 \%$ at the end of 2000 to a level of $21 \%$ from 2001 to 2003 , before the NPL rate reached a pick of $24,2 \%$ from 2003 to 2004 . After that, the overall quarterly default rate remains in a decreasing trend until $13 \%$ in 2010 .

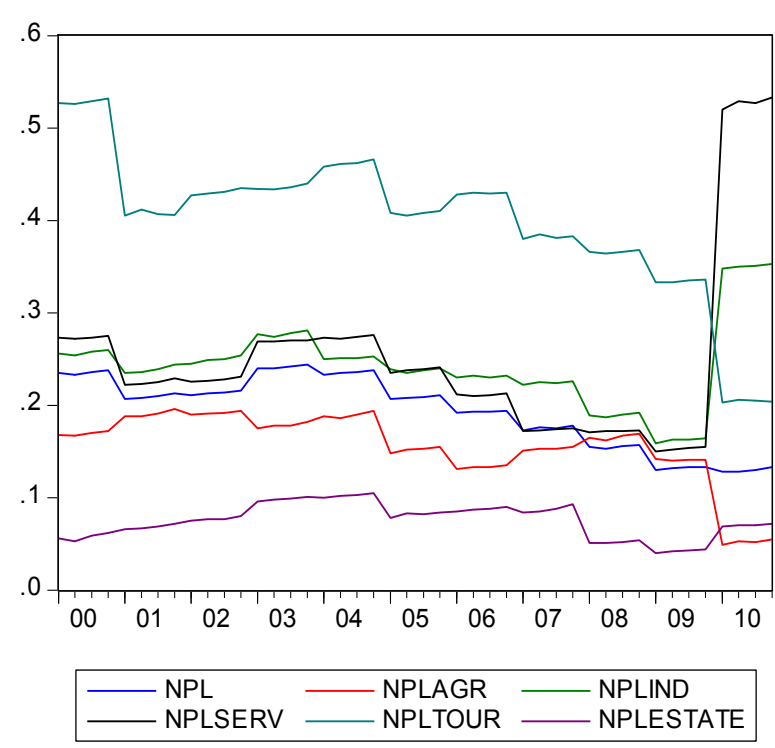

Figure 1. The overall default rate in the time period 2000:1-2010:4

An examination of this figure reveals also that default rates for the industry and tourism generally follow the 
same development. In particular, the NPL for the sector of tourism do approximately remain on the same level during 2000-2001 before a sudden decrease in 2001. Then, it was a steady tendency between 2001 and 2003. After, we notice a substantial increase in 2003-2004, following by a continuous decrease afterwards, only for the tourism sector, when the industry sector default rate increases to $35 \%$ between 2009 and 2010. These donward trends are reflected in a prudential regulation improvement, financial sector opening to foreign investors and promoting the equity market in Tunisia. Default rate in agriculture and estate sector does not follow the other sectors evolution. They seem to converge in the end of observed data but there is significant difference since the beginning of the last decade. Increasing of default rates was important for industry and service sectors which reflects difficulties in these fields.

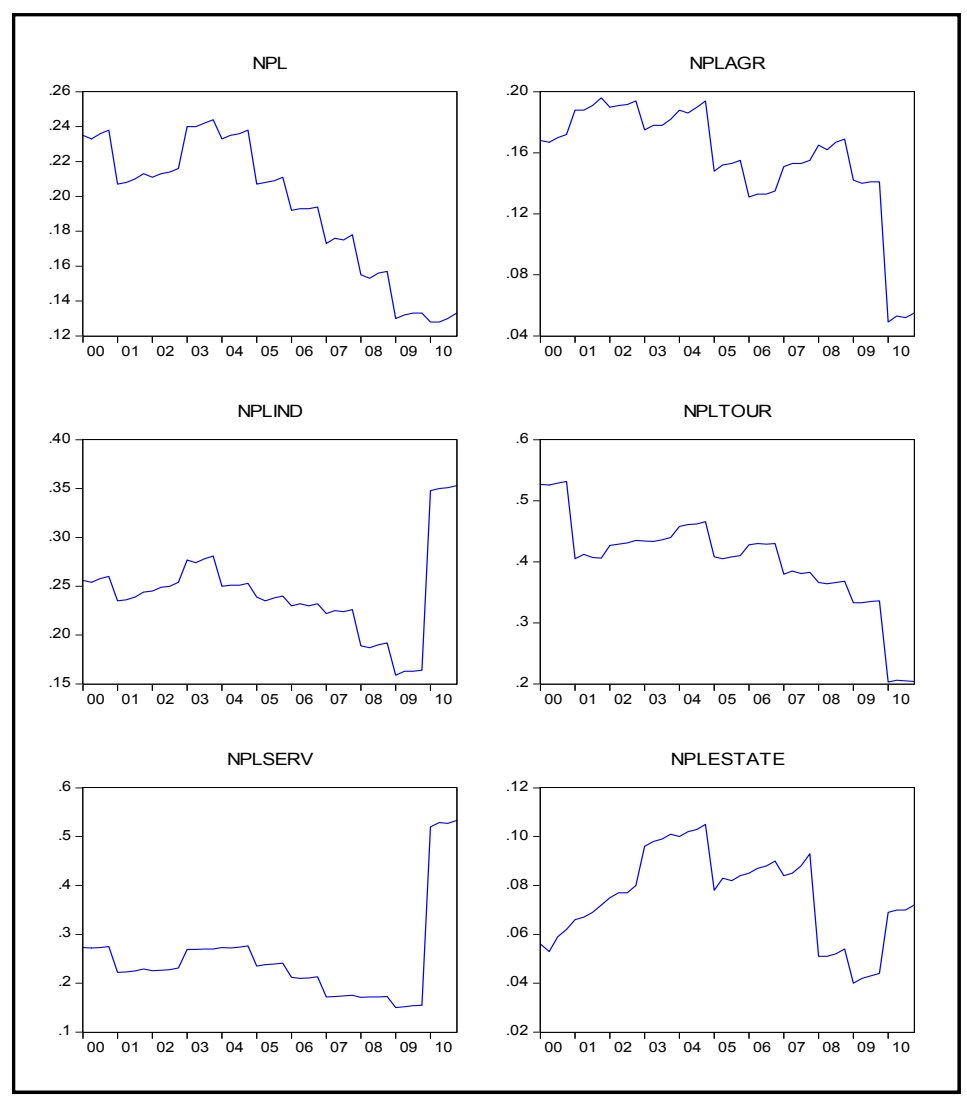

Figure 2. default rates for the five main sectors (2000-2010)

\subsection{Statistical Properties}

Descriptive statistics are presented in Table 1 to Table 4. The sample consists of macroeconomic indexes (global and by sector) or the logit transformation of the Non-Performing Loans rate, the money supply growth M1, the logarithm of the remaining macroeconomic variable considered in our data. The mean, standard deviation, skewness and excess kurtosis of the unconditional distribution of all the variables are computed.

Table 1. Macroeconomic indexes: Y, YTOUR, YSERV, YAGR, YESTATE, YIND

\begin{tabular}{lllllll}
\hline & Y & YTOUR & YSERV & YAGR & YESTATE & YIND \\
\hline Mean & -1.447107 & -1.734947 & -1.147730 & -1.734947 & -2.544623 & -1.153836 \\
Median & -1.340064 & -1.614263 & -1.216803 & -1.614263 & -2.483824 & -1.155425 \\
Maximum & -1.130873 & -1.411485 & 0.132192 & -1.411485 & -2.142863 & -0.605878 \\
Minimum & -1.918759 & -2.965694 & -1.734601 & -2.965694 & -3.178054 & -1.665687 \\
Std. Dev. & 0.264427 & 0.399180 & 0.469960 & 0.399180 & 0.288230 & 0.251802 \\
Skewness & -0.602660 & -2.218687 & 1.510410 & -2.218687 & -0.595557 & 0.116411 \\
Kurtosis & 1.986018 & 7.032616 & 5.202468 & 7.032616 & 2.382170 & 3.551800 \\
\hline
\end{tabular}




\begin{tabular}{lllllll}
\hline Jarque-Bera & 4.548422 & 65.91251 & 25.62306 & 65.91251 & 3.300857 & 0.657596 \\
Probability & 0.102878 & 0.000000 & 0.000003 & 0.000000 & 0.191968 & 0.719788 \\
Sum & -63.67271 & -76.33767 & -50.50014 & -76.33767 & -111.9634 & -50.76880 \\
Sum Sq. Dev. & 3.006631 & 6.851819 & 9.497101 & 6.851819 & 3.572300 & 2.726384 \\
Observations & 44 & 44 & 44 & 44 & 44 & 44 \\
\hline
\end{tabular}

Table 2. Log of GDP (for the economy and per sector)

\begin{tabular}{lllllll}
\hline & LGDP & LGDPTOUR & LGDPSERV & LGDPAGR & LGDPESTATE & LGDPIND \\
\hline Mean & 8.589777 & 5.537931 & 7.581149 & 6.428106 & 5.534327 & 7.131908 \\
Median & 8.582859 & 5.521853 & 7.564184 & 6.460608 & 5.542248 & 7.111919 \\
Maximum & 8.845513 & 5.835097 & 7.989365 & 6.563150 & 5.735627 & 7.327386 \\
Minimum & 8.347093 & 5.290789 & 7.193310 & 6.158461 & 5.270432 & 6.967250 \\
Std. Dev. & 0.151903 & 0.143376 & 0.248990 & 0.097332 & 0.123185 & 0.100449 \\
Skewness & 0.048490 & 0.168947 & 0.082823 & -0.912956 & -0.094239 & 0.235338 \\
Kurtosis & 1.676401 & 2.035351 & 1.650212 & 3.233588 & 1.985998 & 1.938738 \\
Jarque-Bera & 3.229085 & 1.915321 & 3.390505 & 6.212282 & 1.950159 & 2.470989 \\
Probability & 0.198982 & 0.383790 & 0.183553 & 0.044773 & 0.377162 & 0.290691 \\
Sum & 377.9502 & 243.6690 & 333.5706 & 282.8367 & 243.5104 & 313.8039 \\
Sum Sq. Dev. & 0.992207 & 0.883935 & 2.665830 & 0.407363 & 0.652503 & 0.433866 \\
Obs & 44 & 44 & 44 & 44 & 44 & 44 \\
\hline
\end{tabular}

Table 3. Log of indebtedness (for the economy and per sector)

\begin{tabular}{lllllll}
\hline & LD & LDTOUR & LDSERV & LDAGR & LDESTATE & LDIND \\
\hline Mean & 1.870224 & 2.883671 & 1.685105 & 1.228144 & 1.799375 & 2.141644 \\
Median & 1.832961 & 2.921792 & 1.701290 & .201093 & 1.837172 & 2.253952 \\
Maximum & 2.121741 & 3.232509 & 2.266863 & 1.527476 & 2.027405 & 2.311138 \\
Minimum & 1.683774 & 2.528440 & 1.005408 & 0.858049 & 1.542970 & 1.807974 \\
Std. Dev. & 0.136375 & 0.216013 & 0.343499 & 0.184862 & 0.150431 & 0.163499 \\
Skewness & 0.656991 & -0.104088 & -0.221056 & -0.136786 & -0.205061 & -0.563767 \\
Kurtosis & 1.943884 & 1.722559 & 2.193165 & 2.257996 & 1.662631 & 1.727838 \\
Jarque-Bera & 5.210199 & 3.071186 & 1.551818 & 1.146587 & 3.587388 & 5.297839 \\
Probability & 0.073896 & 0.215328 & 0.460285 & 0.563666 & 0.166345 & 0.070728 \\
Sum & 82.28988 & 126.8815 & 74.14463 & 54.03832 & 79.17248 & 94.23234 \\
Sum Sq. Dev. & 0.799718 & 2.006447 & 5.073638 & 1.469478 & 0.973072 & 1.149473 \\
Observations & 44 & 44 & 44 & 44 & 44 & 44 \\
\hline
\end{tabular}

Table 4. General macroeconomic variables

\begin{tabular}{llllllll}
\hline & LTUNIX & LREER & LIR & LBRENT & LINF & LUNEM & M1 \\
\hline Mean & 7.564350 & 4.639251 & -4.554284 & 3.779351 & -4.572121 & -4.469196 & 0.008239 \\
Median & 7.344238 & 4.607916 & -4.554493 & 3.801931 & -4.569104 & -4.467641 & 0.008124 \\
Maximum & 8.591707 & 4.776964 & -4.546307 & 4.764935 & -4.548528 & -4.442900 & 0.028706 \\
Minimum & 6.953812 & 4.552226 & -4.564732 & 2.894281 & -4.599506 & -4.504957 & 0.014167 \\
Std. Dev. & 0.489098 & 0.077286 & 0.005338 & 0.516960 & 0.013403 & 0.015629 & 0.009459 \\
Skewness & 0.680851 & 0.456329 & -0.134246 & 0.099350 & -0.200908 & -0.351376 & -0.107073 \\
Kurtosis & 2.129077 & 1.629524 & 2.191901 & 1.781367 & 2.227066 & 2.351646 & 2.654796 \\
Jarque-Bera & 4.790018 & 4.970445 & 1.329372 & 2.795006 & 1.391285 & 1.676078 & 0.302545 \\
Probability & 0.091172 & 0.083307 & 0.514435 & 0.247213 & 0.498754 & 0.432558 & 0.859613 \\
Sum & 332.8314 & 204.1270 & -200.3885 & 166.2915 & -201.1733 & -196.6446 & 0.362524 \\
Sum Sq. Dev. & 10.28634 & 0.256847 & 0.001225 & 11.49166 & 0.007724 & 0.010503 & 0.003848 \\
Observations & 44 & 44 & 44 & 44 & 44 & 44 & 44 \\
\hline
\end{tabular}


During the observed period, Service index shows the highest average probability of default, followed by the Industry index; while, the estate index corresponds to the lowest probability. Then, the riskiest sector is service, whereas, the estate sector is the least risky. The average key macroeconomic default shows normal distribution for global economy, industry and estate per the JB test. The estimates for skewness and kurtosis indicate that the agriculture, service and industry indexes deviate significantly from normality, suggesting a leptokurtic shape. Standard deviation of Service is higher than that of Tourism or Agriculture. Then, Considerable volatility and default risks are prevalent in the economy. Economy could face credit risk as suggested by the large negative maximum value. Otherwise, the large excess kurtosis suggests that extreme events prevail mainly in the tourism, service and agriculture sectors. Thus, whatever the minimum credit could be considerable; there is no consistent default probability for the economy. Credit Risk management is therefore useful for monetary authorities to prevent the risk exposure.

It also appears that, relatively to the sector, the probability of default increases with the real amount of GDP; whereas, it doesn't suit the corresponding mean of indebtedness.

Moreover, we note that during the observed period, service GDP shows the highest average followed by the industry GDP and the least one is the estate and the tourism sector. While, the tourism sector indebtedness is notably higher than other sectors followed by the industry one.

\subsection{Estimation Technique}

Data analysis covers a unit root test (test for stationarity) using the Augumented Dickey-Fuller (ADF). Then, we use the vector-autoregression (VAR) framework and analyse the existence of a long-run relationship using the co-integration test. We use the co-integration evaluation to establish if there is any long-run equilibrium relationship between the macroeconomic indexes representing specific default rates and macroeconomic factors by adopting the multivariate Error Correction Model (ECM) which follows the Johansen (1995). If the variables are stationary, then VAR model may be adequate to explain the relationship. If the variables are integrated that is $\mathrm{I}(\mathrm{d})$, we must determine whether the model is cointegrating and hence may have an error correction specification (a linear combination of two or more non-stationary(with unit root) series may become stationary or $\mathrm{I}(0)$; the stationary linear combination may be interpreted as long-run equilibrium relationship between the variables.

\subsubsection{Tests of Order of Integration}

To determine the order of integration for the variables in the study, we choose to use the augmented Dickey-Fuller (ADF) and Phillips-Perron tests to examine the properties of variables. The results are presented in Table 5 for the level and first difference by taking into consideration the constant and trend in the series. At the level of the variables, the ADF statistics shows that the null hypothesis of non-stationary for M1, Inf, Unem,

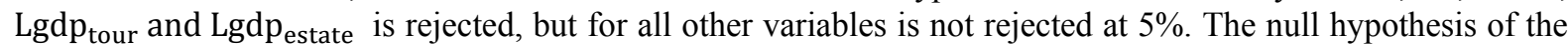
same test is rejected for the first log difference of Tunix, Reer, I, Brent, the indebtedness and gdp of global economy and of each sector studied. Also, ADF rejects the null hypothesis for the first difference of global and sectorial macroeconomic index. Therefore, we can conclude that M1, Inf, and Unem Lgdp tour and Lgdp estate variables are stationary in levels and all other variables are stationary in first difference.

Table 5. The results of ADF test variable level and first difference

\begin{tabular}{lccccc}
\hline \multirow{2}{*}{ Variables } & \multicolumn{2}{c}{ ADF } & & \multicolumn{2}{c}{ PP } \\
\cline { 2 - 3 } \cline { 5 - 6 } \cline { 5 - 6 } LGDP & Level & First difference & & Level & First difference \\
\hline LGDPagr & -2.3480 & $-5,8942^{* * *}$ & & -2.4298 & $-6,0130^{* * *}$ \\
LGDPind & -1.9714 & $-5,3612^{* * *}$ & & $-2,2816$ & $-5,3669^{* * *}$ \\
LGDPserv & -2.8324 & $-7,1631^{* * *}$ & & $-2,9343$ & $-7,1631^{* * *}$ \\
LGDPtour & -1.9078 & $-7,1687^{* * *}$ & & $-2,4001$ & $-6,8629^{* * *}$ \\
LGDPestate & -2.8847 & $-7,7290^{* * *}$ & & $-3,6344^{* *}$ & \\
LD & $-5,4654^{* * *}$ & & & $-5,4315^{* * *}$ & \\
LDagr & -1.1039 & $-4,8998^{* * *}$ & & $-1,6221$ & $-4,4982^{* * *}$ \\
LDind & -2.1157 & $-4,7664^{* * *}$ & & $-1,1988$ & $-4,6886^{* * *}$ \\
LDserv & -1.8837 & $-6,1187^{* * *}$ & & $-2,0156$ & $-6,1096^{* * *}$ \\
LDtour & -1.3483 & $-6,7027^{* * *}$ & & $-1,3483$ & $-6,8439^{* * *}$ \\
LDestate & -2.9034 & $-5,6606^{* * *}$ & & $-2,6104$ & $-11,1676^{* * *}$ \\
LTunix & -2.9527 & $-7,4256^{* * *}$ & & $-2,9527$ & $-8,6726^{* * *}$ \\
\hline
\end{tabular}




\begin{tabular}{lcccc}
\hline Lir & -2.6639 & $-4,0399^{* *}$ & $-2,1763$ & $-4,0395^{* *}$ \\
Lreer & -1.1352 & $-5,1820^{* * *}$ & $-1,0138$ & $-7,6944^{* * *}$ \\
Lbrent & $-3,3762^{*}$ & $-5,7846^{* * *}$ & $-2,4382$ & $-5,2636^{* * *}$ \\
Lunem & $-4,1813^{* *}$ & & $-4,0132 * *$ & \\
Linf & $-5,5992^{* * *}$ & & $-8,3142^{* * *}$ & \\
M1 & $-10,8536^{* * *}$ & & $-11,1584^{* * *}$ & \\
\hline Macroeconomic index series & & & \\
\hline Y & -2.5676 & -2.3040 & $-1,8457$ & $-7,8323^{* * *}$ \\
Yagr & -1.6649 & $-7,2986^{* * *}$ & $-1,6131$ & $7,5259^{* * *}$ \\
Yind & -1.4822 & $-6,4346^{* * *}$ & $-1,6803$ & $-6,4345^{* * *}$ \\
Yserv & -1.0590 & $-6,4894^{* * *}$ & $-1,1217$ & $-6,4983^{* * *}$ \\
Ytour & -1.6303 & $-7,2268^{* * *}$ & $-1,6131$ & $-7,5259^{* * *}$ \\
Yestate & -2.0868 & $-6,7034^{* * *}$ & $-2,0868$ & $-6,7034^{* * *}$ \\
\hline
\end{tabular}

Note. Tests for unit roots have been carried out on EViews 6.0 with constant and time trend. *,**, *** indicate Significance at $10 \%, 5 \%$ and $1 \%$ levels respectively. The $1 \%, 5 \%$ and $10 \%$ ADF and Philips Perron critical values for the model are respectively $-4.1923,-3.5207$ and -3.1912 for ADF and $-4.1864,-3.5180$ and -3.1897 for PP. The p-values used for the tests are the MacKinnon (1996) one-sided $p$-values. The optimal lagged differences are selected based on Akaike info criterion.

\subsubsection{Co-Integration Test}

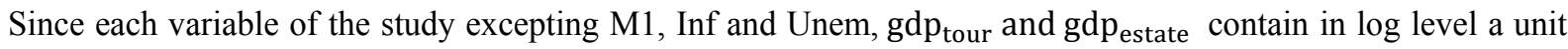
root, they could be feasibly employed in the cointegration test. Then, we conduct Johanson-Juselius cointegration test (Johansen \& Juselius, 1990) for common stochastic trend. The null hypothesis is that there is no cointegrating vector $(r a n k=0)$, and the alternative hypothesis is that there is a single cointegrating vector $($ rank=1). The approach (Johansen, 1988) gives two likelihood ratios test, Trace Value and maximum Eigen Value, for detecting number of cointegrating vectors $r$.

Table 6. Tests for the number of cointegrating vectors

\begin{tabular}{|c|c|c|c|c|c|c|}
\hline \multicolumn{7}{|l|}{ Model for the tourism sector } \\
\hline & trace statistic & critical value $5 \%$ & Prob.** & max-eigen statistic & critical value $5 \%$ & Prob.** \\
\hline None * & 61.58563 & 47.85613 & 0.0016 & 35.55735 & 27.58434 & 0.0038 \\
\hline At most 1 & 26.02827 & 29.79707 & 0.1279 & 13.86319 & 21.13162 & 0.3764 \\
\hline \multicolumn{7}{|l|}{ Model for the estate sector } \\
\hline Hypothesized $\mathrm{N}^{\circ}$ of $\mathrm{CE}(\mathrm{s})$ & trace statistic & critical value $5 \%$ & Prob.** & max-eigen statistic & critical value $5 \%$ & Prob.** \\
\hline None * & 52.39078 & 47.85613 & 0.0176 & 31.88109 & 27.58434 & 0.0131 \\
\hline At most 1 & 20.50969 & 29.79707 & 0.3889 & 10.35092 & 21.13162 & 0.7112 \\
\hline \multicolumn{7}{|c|}{ Model for the agriculture sector } \\
\hline & trace statistic & critical value $5 \%$ & Prob.** & max-eigen statistic & critical value $5 \%$ & Prob.** \\
\hline None * & 70.26279 & 69.81889 & 0.0461 & 30.68661 & 33.87687 & 0.1147 \\
\hline At most 1 & 39.57618 & 47.85613 & 0.2380 & 16.88397 & 27.58434 & 0.5899 \\
\hline \multicolumn{7}{|l|}{ Model for the industry sector } \\
\hline & trace statistic & critical value $5 \%$ & Prob.** & max-eigen statistic & critical value $5 \%$ & Prob.** \\
\hline None * & 74.34162 & 69.81889 & 0.0208 & 41.09235 & 33.87687 & 0.0058 \\
\hline At most 1 & 33.24927 & 47.85613 & 0.5431 & 17.28946 & 27.58434 & 0.5552 \\
\hline \multicolumn{7}{|l|}{ Model for the industry sector } \\
\hline & trace statistic & critical value $5 \%$ & Prob.** & max-eigen statistic & critical value $5 \%$ & Prob.** \\
\hline None * & 38.74059 & 47.85613 & 0.2707 & 28.16403 & 27.58434 & 0.0421 \\
\hline At most 1 & 10.57656 & 29.79707 & 0.9705 & 7.338768 & 21.13162 & 0.9394 \\
\hline \multicolumn{7}{|l|}{ Model for the global economy } \\
\hline & trace statistic & critical value $5 \%$ & Prob.** & max-eigen statistic & critical value $5 \%$ & Prob.** \\
\hline None * & 83.73364 & 69.81889 & 0.0026 & 34.80297 & 33.87687 & 0.0387 \\
\hline At most $1 *$ & 48.93067 & 47.85613 & 0.0395 & 19.85279 & 27.58434 & 0.3514 \\
\hline At most 2 & 29.07788 & 29.79707 & 0.0604 & 15.67650 & 21.13162 & 0.2443 \\
\hline
\end{tabular}


Results of both tests are reported in Table 6, where $r$ represents the cointegration rank. When applying the cointegration test on e-views, we choose the case 3 (assumption where the level data has a linear trend but the cointegrating equations have only intercepts). Additionally, Johansen's procedure requires estimating a VAR(p); the optimal number of lag $p$ of the VAR is selected on the basis of both the Akaike Information Criterion (AIC) and the Schwarz Bayesian Information Criterion (SBIC). If empirical evidence of cointegration is found to exist between each macroeconomic key for default and the other macroeconomic variables, this will have important implications for the existence of a stable long- run relationship between movements in macroeconomic factors and changes in default rate over longer periods of time.

After, we combine all these stationary variables per sector and we find the following long-term relationships for each model, global and sectorial. The second step consists in capturing the short-run dynamics of each model through error correction mechanism.

\subsubsection{Model for Agriculture Sector}

As first step in the multivariate cointegration analysis, trace statistic recognized one cointegrating Vector that will be used in order to establish the long-run relationships among the agriculture variables. When we estimated the VAR with these variables in log form, the AIC selects a VAR model with 2 lags, while the SIC selects a model with 1 lags. We estimated the VAR(2) model selected by the SIC given that it is the more parsimonious in terms of coefficients to estimate. The results for Trace statistic is reported in Table 6.

The cointegrating vector normalized on agriculture index $y_{\text {agr }}$ has coefficients estimated as shown in Table 7.

Table 7. Agriculture VECM

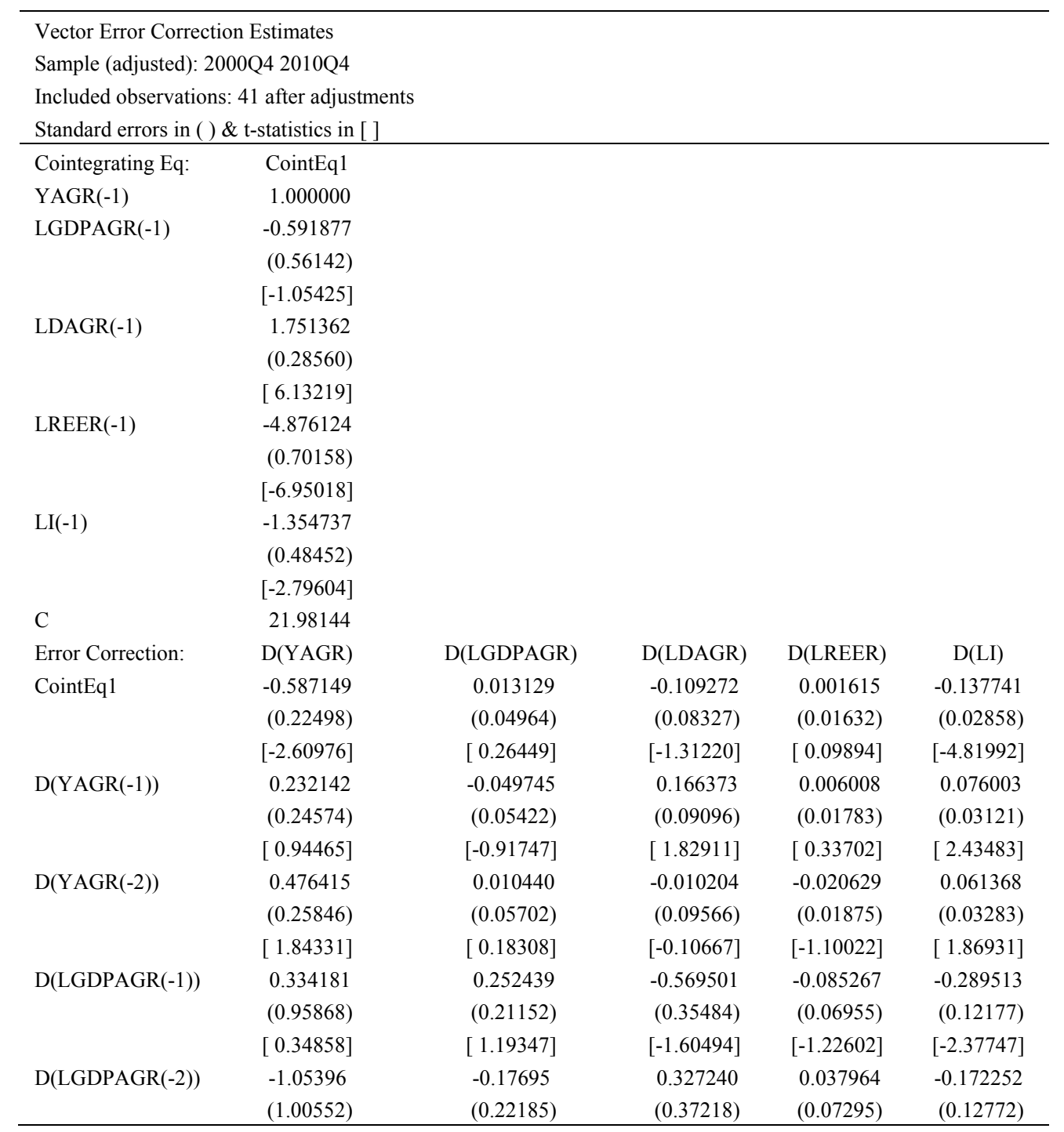




\begin{tabular}{|c|c|c|c|c|c|}
\hline \multirow{3}{*}{ D(LDAGR(-1)) } & {$[-1.04817]$} & {$[-0.79761]$} & {$[0.87926]$} & [0.52044] & {$[-1.34865]$} \\
\hline & 0.247417 & -0.113623 & 0.456780 & 0.011049 & 0.116899 \\
\hline & $(0.51154)$ & $(0.11286)$ & $(0.18934)$ & $(0.03711)$ & $(0.06498)$ \\
\hline & [ 0.48367$]$ & {$[-1.00673]$} & {$[2.41250]$} & {$[0.29773]$} & [ 1.79910$]$ \\
\hline \multirow[t]{3}{*}{ D(LDAGR(-2)) } & 1.274887 & 0.046661 & -0.155147 & -0.007707 & 0.236792 \\
\hline & $(0.61824)$ & $(0.13640)$ & $(0.22883)$ & $(0.04485)$ & $(0.07853)$ \\
\hline & [2.06213] & {$[0.34208]$} & {$[-0.67800]$} & {$[-0.17185]$} & [ 3.01533] \\
\hline \multirow[t]{3}{*}{ D(LREER(-1)) } & -2.448571 & 0.550766 & -0.31106 & -0.185559 & -0.826292 \\
\hline & $(2.86218)$ & $(0.63149)$ & (1.05939) & $(0.20764)$ & $(0.36356)$ \\
\hline & {$[-0.85549]$} & {$[0.87217]$} & {$[-0.29362]$} & {$[-0.89367]$} & {$[-2.27280]$} \\
\hline \multirow[t]{3}{*}{ D(LREER(-2)) } & -5.791809 & -1.409698 & 2.760251 & -0.005177 & -0.313462 \\
\hline & (2.70779) & $(0.59743)$ & (1.00224) & $(0.19644)$ & $(0.34395)$ \\
\hline & {$[-2.13895]$} & {$[-2.35962]$} & [ 2.75407] & {$[-0.02636]$} & {$[-0.91137]$} \\
\hline \multirow[t]{3}{*}{$\mathrm{D}(\mathrm{LI}(-1))$} & -1.6667 & -0.123493 & -0.497951 & -0.056832 & -0.202781 \\
\hline & $(1.45180)$ & $(0.32031)$ & $(0.53736)$ & $(0.10532)$ & $(0.18441)$ \\
\hline & {$[-1.14802]$} & {$[-0.38554]$} & {$[-0.92666]$} & {$[-0.53960]$} & {$[-1.09963]$} \\
\hline \multirow[t]{3}{*}{$\mathrm{D}(\mathrm{LI}(-2))$} & -2.06924 & -0.022742 & 0.189855 & 0.016954 & -0.435338 \\
\hline & $(1.32424)$ & $(0.29217)$ & $(0.49015)$ & $(0.09607)$ & $(0.16821)$ \\
\hline & {$[-1.56258]$} & {$[-0.07784]$} & {$[0.38734]$} & {$[0.17648]$} & {$[-2.58811]$} \\
\hline \multirow[t]{3}{*}{$\mathrm{C}$} & -0.065602 & -0.004666 & 0.015259 & -0.006 & -0.007434 \\
\hline & $(0.03887)$ & $(0.00858)$ & $(0.01439)$ & $(0.00282)$ & $(0.00494)$ \\
\hline & {$[-1.68791]$} & {$[-0.54416]$} & [ 1.06071$]$ & {$[-2.12788]$} & {$[-1.50573]$} \\
\hline R-squared & 0.276812 & 0.305943 & 0.436956 & 0.148824 & 0.617318 \\
\hline Adj. R-squared & 0.002500 & 0.042680 & 0.223388 & -0.174036 & 0.472163 \\
\hline Sum sq. resids & 1.131585 & 0.055084 & 0.155026 & 0.005955 & 0.018257 \\
\hline S.E. equation & 0.197535 & 0.043583 & 0.073114 & 0.014330 & 0.025091 \\
\hline F-statistic & 1.009113 & 1.162120 & 2.045981 & 0.460955 & 4.252815 \\
\hline Log likelihood & 15.41755 & 77.37903 & 56.16707 & 122.9828 & 100.0170 \\
\hline Akaike AIC & -0.16671 & -3.189221 & -2.154491 & -5.413797 & -4.293513 \\
\hline Schwarz SC & 0.334823 & -2.687688 & -1.652958 & -4.912264 & -3.79198 \\
\hline Mean dependent & -0.030688 & 0.002829 & -0.003123 & -0.00457 & -0.005116 \\
\hline S.D. dependent & 0.197783 & 0.044544 & 0.082966 & 0.013226 & 0.034536 \\
\hline \multicolumn{2}{|c|}{ Determinant resid covariance (dof adj.) } & $2.40 \mathrm{E}-14$ & & & \\
\hline \multicolumn{2}{|c|}{ Determinant resid covariance } & $4.25 \mathrm{E}-15$ & & & \\
\hline \multicolumn{2}{|l|}{ Log likelihood } & 387.4768 & & & \\
\hline \multicolumn{2}{|c|}{ Akaike information criterion } & -15.73057 & & & \\
\hline \multicolumn{2}{|l|}{ Schwarz criterion } & -13.01394 & & & \\
\hline
\end{tabular}

The first normalized equation1 was estimated as below:

$$
\begin{array}{r}
y_{\text {agr }}=-21,9814+0.5918 \mathrm{Lgdp} p_{\text {agr }}-1,7513 \mathrm{LD}_{\text {agr }}+4,8761 \mathrm{Lreer}+1,3547 \mathrm{Lir}+\varepsilon_{t} \\
{[-1.05425] \quad[6.13219] \quad[-6.95018] \quad[-2.79604]}
\end{array}
$$

According to this long-run relationship, agriculture index $\left(y_{a g r}\right)$ shows significantly negative relation with indebtedness in agriculture sector $\left(D_{a g r}\right)$ in long-run which suggested that indebtedness increase worsens the default probability in this sector. The positive relationship between $y_{a g r}$ and agriculture gross domestic product $L g d p_{a g r}$ is insignificant in the long-run. Normalized equation (6) showed that there is a significant positive relationship between $y_{a g r}$ and interest rate in one side and between $y_{a g r}$ and real effective exchange rate in other side. This implied that along with the increase in exchange rate, there was a positive extensive effect on non performing loans proportion in agriculture sector. Also, an increase in short-term interest rate aggravates the default rate in agriculture sector in long-term.

One further step of this study was the implementation of the ECM to capture the short-run relations and impacts of macroeconomic variables on default risk. The results of vector error correction model are reported in Table 7. The results of vector error correction model (VECM) depicted that the error correction coefficient is significant with negative signs in $y_{a g r}$, which imply short-term adjustments of this series by $58 \%$ in a quarter. Then, it took approximately 6 months $(1 / 0.58)$ to eliminate the disequilibrium. Regarding the signs of the regression coefficients of the estimated models, we find that the default risk is negatively related to the real exchange rate 
lagged two period at $10 \%$ significance level and positively related to the agriculture indebtedness in its second lag and to its own second lag. It also appears from the ECM a bidirectional causality between the agriculture sector NPL rate and its indebtedness level.

\subsubsection{Model for Estate Sector}

The results for Co-integration show that the null hypothesis of no cointegration cannot be accepted at $5 \%$ significance level and there exists one cointegration relationship among the estate sector default probability, the indebtedness in the same sector, the short term interest rate and the oil price:

$$
\begin{array}{r}
y_{\text {estate }}=0,2217-3,7734 \text { LD }_{\text {estate }}-3,8872 \text { Lir-1,9794 Lbrent }+\varepsilon_{t} \\
{[3.63705] \quad[4.43906]}
\end{array}
$$

Then, the non performing loans rate in the estate sector share a long-term equilibrium relation with a set of macroeconomic variables. Lag 3 is chosen since the AIC indicates this value. From the selected long-term relationship, we estimate the dynamic equations in the form of error correction models that describe the dynamic short-term evolution of the former series.

The estimated coefficient of error-correction term in the $\mathrm{y}_{\text {estate }}$ equation is statistically significant and has a negative sign, its relative value $(-0.288129)$ shows the rate of convergence to the equilibrium state per quarter. Precisely, the speed of adjustment of any disequilibrium towards a long-run equilibrium is about $28,8 \%$, that means adjusted approximately in one year. In addition, The ECM model for short-term fluctuations unveils:

- a significant unidirectional relation between $y_{\text {estate }}$ and the third lag of the indebtedness in the estate sector Ldestate showing that an increase in the indebtedness is followed after three quarters by a decrease in the default rate. In the same time, the two lagged period the default rate affect negatively the indebtedness in short term at a $10 \%$ level of significance.

- the coefficient of $\mathrm{Li}$ in equation $\mathrm{D}$ (yestate) is positive and significantly different from 0 at a level of $10 \%$. This result shows that an increase in short-term interest rate is followed after 3 lags by an aggravation of the default rate. This situation doesn't remain in the long term. Indeed, an increase in Li induces the decrease of the default risk in the long-run.

- a positive impact of a one lag delayed oil price on the estate default rate.

\subsubsection{Model for Service Sector}

Under the Johansen Cointegration Test, it could be said that there are cointegrated vectors (Table 8). The max-eigenvalue test indicates 1 cointegrated equation at the $5 \%$ significance level. The normalized cointegrated vector for $y_{\text {serv }}$ is:

$$
\begin{array}{r}
y_{\text {serv }}=-9,8805+0,8675 \text { Lgdp }_{\text {serv }}-1,9919 \text { Lir-1,0028 Lbrent }+\varepsilon_{t} \\
{[-1.91664] \quad[4.65487] \quad[5.57282]}
\end{array}
$$

The service sector default rate is affected in the long run by the GDP in service sector, a 10 point GDPserv increase cause a 8,6 point increase in the service sector index and consequently, a default risk increase in the service sector. While, the short term interest rate and oil price mitigate the default risk of the service sector. All these long term results are contrary to our hypothesis.

The Error correction mechanism provides a significant negative coefficient in $\mathrm{y}_{\text {service, }}$ which shows that the disequilibrium is quickly corrected to reconcile the short-run and long-run behavior. In the short-run, we notice that a 10 point increase in $y_{\text {serv }}$ first lag, in third lag short-term interest rate and in oil price first lag cause

\begin{tabular}{|c|c|}
\hline \multicolumn{2}{|c|}{ Vector Error Correction Estimates } \\
\hline \multicolumn{2}{|c|}{ Sample (adjusted): 2001Q1 2010Q4 } \\
\hline \multicolumn{2}{|c|}{ Included observations: 40 after adjustments } \\
\hline \multicolumn{2}{|c|}{ Standard errors in ( ) \& t-statistics in [ ] } \\
\hline Cointegrating Eq: & CointEq1 \\
\hline YSERV(-1) & 1.000000 \\
\hline LGDPSERV(-1) & -0.86751 \\
\hline & $(0.45262)$ \\
\hline
\end{tabular}
respective increases of 5,4 points, 31,6 points and 9,3 points increases in service sector index. That means an increase of service sector default rate in the short-term.

Table 9. Service VECM 


\begin{tabular}{|c|c|c|c|c|}
\hline & {$[-1.91664]$} & & & \\
\hline \multirow[t]{3}{*}{ LI(-1) } & 1.991954 & & & \\
\hline & $(0.42793)$ & & & \\
\hline & [ 4.65487$]$ & & & \\
\hline \multirow[t]{3}{*}{ LBRENT(-1) } & 1.002805 & & & \\
\hline & $(0.17995)$ & & & \\
\hline & [ 5.57282] & & & \\
\hline $\mathrm{C}$ & 9.880552 & & & \\
\hline Error Correction: & D(YSERV) & D(LGDPSERV) & $\mathrm{D}(\mathrm{LI})$ & D(LBRENT) \\
\hline \multirow[t]{3}{*}{ CointEq1 } & -1.128253 & 0.006328 & 0.031765 & -0.301942 \\
\hline & $(0.20696)$ & $(0.01331)$ & $(0.02527)$ & $(0.16039)$ \\
\hline & {$[-5.45149]$} & {$[0.47533]$} & [ 1.25695$]$ & {$[-1.88259]$} \\
\hline \multirow[t]{3}{*}{ D(YSERV(-1)) } & 0.545885 & -0.010737 & 0.015178 & 0.091542 \\
\hline & $(0.17688)$ & $(0.01138)$ & $(0.02160)$ & $(0.13708)$ \\
\hline & [ 3.08615$]$ & {$[-0.94361]$} & {$[0.70276]$} & [0.66782] \\
\hline \multirow[t]{3}{*}{ D(YSERV(-2)) } & 0.691468 & -0.003204 & 0.018129 & 0.172340 \\
\hline & $(0.18013)$ & $(0.01159)$ & $(0.02199)$ & $(0.13959)$ \\
\hline & [ 3.83882$]$ & {$[-0.27651]$} & {$[0.82426]$} & [ 1.23462$]$ \\
\hline \multirow[t]{3}{*}{ D(YSERV(-3)) } & 0.821363 & -0.001789 & -0.011498 & 0.288842 \\
\hline & $(0.18862)$ & $(0.01213)$ & $(0.02303)$ & $(0.14617)$ \\
\hline & [ 4.35462] & {$[-0.14742]$} & {$[-0.49924]$} & [ 1.97606$]$ \\
\hline \multirow[t]{3}{*}{ D(LGDPSERV(-1)) } & 1.884985 & -0.178056 & 0.399471 & -0.954381 \\
\hline & (2.90286) & $(0.18674)$ & $(0.35445)$ & $(2.24958)$ \\
\hline & [ 0.64935$]$ & {$[-0.95349]$} & [ 1.12700$]$ & {$[-0.42425]$} \\
\hline \multirow[t]{3}{*}{ D(LGDPSERV(-2)) } & 2.374827 & -0.24587 & 0.004934 & -0.07099 \\
\hline & $(2.89717)$ & $(0.18638)$ & $(0.35376)$ & $(2.24517)$ \\
\hline & {$[0.81971]$} & {$[-1.31922]$} & [ 0.01395$]$ & {$[-0.03162]$} \\
\hline \multirow[t]{3}{*}{ D(LGDPSERV(-3)) } & 3.846698 & -0.189036 & -0.421624 & 2.380239 \\
\hline & $(2.83340)$ & $(0.18227)$ & $(0.34597)$ & $(2.19575)$ \\
\hline & [ 1.35763$]$ & {$[-1.03710]$} & {$[-1.21866]$} & [ 1.08402$]$ \\
\hline \multirow[t]{3}{*}{$\mathrm{D}(\mathrm{LI}(-1))$} & 1.330695 & -0.088664 & 0.233344 & 0.038308 \\
\hline & (1.69971) & $(0.10934)$ & $(0.20754)$ & $(1.31720)$ \\
\hline & [ 0.78290$]$ & {$[-0.81088]$} & [ 1.12431$]$ & [ 0.02908$]$ \\
\hline \multirow[t]{3}{*}{$\mathrm{D}(\mathrm{LI}(-2))$} & 1.170413 & 0.075256 & 0.154242 & 1.246132 \\
\hline & (1.65999) & $(0.10679)$ & $(0.20269)$ & $(1.28641)$ \\
\hline & [ 0.70507$]$ & {$[0.70473]$} & [ 0.76096] & [ 0.96869$]$ \\
\hline \multirow[t]{3}{*}{$\mathrm{D}(\mathrm{LI}(-3))$} & 3.164403 & 0.010972 & -0.086297 & -0.192531 \\
\hline & (1.57759) & $(0.10149)$ & $(0.19263)$ & $(1.22256)$ \\
\hline & [ 2.00584$]$ & [0.10811] & {$[-0.44799]$} & {$[-0.15748]$} \\
\hline \multirow[t]{3}{*}{ D(LBRENT(-1)) } & 0.934702 & 0.037235 & 0.093137 & 0.482385 \\
\hline & $(0.24722)$ & $(0.01590)$ & $(0.03019)$ & $(0.19158)$ \\
\hline & [ 3.78084$]$ & [2.34126] & [ 3.08534$]$ & [ 2.51787$]$ \\
\hline \multirow[t]{3}{*}{ D(LBRENT(-2)) } & 0.789265 & 0.010585 & -0.081604 & -0.063659 \\
\hline & $(0.34106)$ & $(0.02194)$ & $(0.04165)$ & $(0.26431)$ \\
\hline & [2.31412] & [ 0.48243$]$ & {$[-1.95948]$} & {$[-0.24085]$} \\
\hline \multirow[t]{3}{*}{ D(LBRENT(-3)) } & 0.732011 & -0.030136 & -0.013771 & -0.006988 \\
\hline & $(0.32591)$ & $(0.02097)$ & $(0.03980)$ & $(0.25257)$ \\
\hline & [ 2.24603] & {$[-1.43738]$} & {$[-0.34603]$} & {$[-0.02767]$} \\
\hline \multirow[t]{3}{*}{$\mathrm{C}$} & -0.197671 & 0.029878 & -0.00331 & -0.013908 \\
\hline & $(0.11599)$ & $(0.00746)$ & $(0.01416)$ & (0.08989) \\
\hline & [-1.70419] & [ 4.00422] & {$[-0.23373]$} & {$[-0.15473]$} \\
\hline R-squared & 0.640016 & 0.524816 & 0.614465 & 0.400018 \\
\hline Adj. R-squared & 0.460024 & 0.287224 & 0.421697 & 0.100027 \\
\hline Sum sq. resids & 1.232965 & 0.005102 & 0.018383 & 0.740462 \\
\hline S.E. equation & 0.217765 & 0.014009 & 0.026590 & 0.168758 \\
\hline F-statistic & 3.555805 & 2.208895 & 3.187594 & 1.333434 \\
\hline
\end{tabular}




\begin{tabular}{lcccr}
\hline Log likelihood & 12.83161 & 122.5806 & 96.94641 & 23.02966 \\
Akaike AIC & 0.058420 & -5.42903 & -4.14732 & -0.451483 \\
Schwarz SC & 0.649528 & -4.837922 & -3.556213 & 0.139625 \\
Mean dependent & 0.027540 & 0.018304 & -0.005244 & 0.027796 \\
S.D. dependent & 0.296348 & 0.016593 & 0.034966 & 0.177889 \\
Determinant resid covariance (dof adj.) & $1.08 \mathrm{E}-10$ & & \\
Determinant resid covariance & $1.92 \mathrm{E}-11$ & & \\
Log likelihood & 266.4763 & & \\
Akaike information criterion & -10.32381 & & \\
Schwarz criterion & -7.790496 & & \\
\hline
\end{tabular}

\subsubsection{Model for Tourism Sector}

There is a long run relationship between the tourism sector index, indebtedness of the same sector, the short-term interest rate in the economy, the international oil price. The estimated cointegrating equation is as follows:

$$
\begin{array}{r}
y_{\text {tour }}=-75,8691+13,7352 \text { Ld }_{\text {tour }}-5,343 \text { Lir }+4,94 \text { Lbrent }+\varepsilon_{t} \\
{[-4.53354] \quad[1.98557] \quad[-4.45386]}
\end{array}
$$

We notice a significant positive effect of tourism indebtedness and brent oil price on the non-performing loans in tourism in long-term as the hypothesis stipulated; whereas, the interest rate has negative impact on the tourism credit risk, contrarily to the preliminary assumption.

In $y_{\text {tour }}$ equation, the estimated coefficient of the error correction term is not statistically significant. It means the error term does not contribute in explaining the changes in tourism default rate. And, when estimating of the four variable VEC model chosen with Lag 2 according to the AIC test, we find that there exists an unidirectional causality from $y_{\text {tour }}$ lagged one period to indebtedness, and $y_{\text {tour }}$ lagged two period to interest rate in the short-run.

\subsubsection{Model for Industry Sector}

The trace test results show that yind, Lgdpind, Ldind, Li and Lbrent variables are cointegrated at $5 \%$ of significance. The long-run relationship between the variables is:

$$
\begin{gathered}
y_{\text {ind }}=468,4333-62,5394 \mathrm{Lgdp}_{\text {ind }}-160,7330 \mathrm{LD}_{\text {ind }}-201,2026 \mathrm{Lir}-72,7443 \mathrm{Lbrent}+\varepsilon_{t} \\
{[0.75245] \quad[3.47795] \quad[5.06316]}
\end{gathered}
$$

The long term coefficients results reveal that industrial production is not statistically significant. While, the sector indebtedness, the short-term interest rate and the oil prices have significant negative long run effect on industry default rate which is contrary to the study hypothesis.

Error Correction Representation of above long run relationship is reported in Table 11 which captures the short-run dynamics of relationship among macroeconomic variables and credit risk in industry. We note that the estimated coefficient of the error correction term $y_{\text {ind }}$ is negative and statistically significant at $5 \%$ level. Thus, the error correction term contributes in explaining the changes in industry default rate; in short term, there exist a

\begin{tabular}{|c|c|}
\hline Vector Error Correctio & \\
\hline Sample (adjusted): 200 & \\
\hline Included observations: & djustments \\
\hline Standard errors in ( ) \& & $\sin []$ \\
\hline Cointegrating Eq: & CointEq1 \\
\hline $\mathrm{YIND}(-1)$ & 1.000000 \\
\hline LGDPIND(-1) & 62.53945 \\
\hline & (83.1144) \\
\hline & {$[0.75245]$} \\
\hline $\operatorname{LDIND}(-1)$ & 160.7330 \\
\hline & $(46.2149)$ \\
\hline
\end{tabular}
bidirectional causality between $y_{\text {ind }}$ and interest rate and a unidirectional causality from oil price to industry default risk.

Table 11. Industry VECM 


\begin{tabular}{|c|c|c|c|c|c|}
\hline & [ 3.47795] & & & & \\
\hline \multirow[t]{3}{*}{$\mathrm{LI}(-1)$} & 201.2026 & & & & \\
\hline & (39.7385) & & & & \\
\hline & [ 5.06316] & & & & \\
\hline \multirow[t]{3}{*}{ LBRENT(-1) } & 72.74430 & & & & \\
\hline & (15.0589) & & & & \\
\hline & [ 4.83066] & & & & \\
\hline $\mathrm{C}$ & -468.4333 & & & & \\
\hline Error Correction: & $\mathrm{D}(\mathrm{YIND})$ & D(LGDPIND) & $\mathrm{D}(\mathrm{LDIND})$ & $\mathrm{D}(\mathrm{LI})$ & $\mathrm{D}$ (LBRENT) \\
\hline \multirow[t]{3}{*}{ CointEq1 } & -0.005909 & -0.000651 & -0.000293 & 0.000365 & -0.003755 \\
\hline & $(0.00255)$ & $(0.00033)$ & $(0.00066)$ & $(0.00042)$ & $(0.00270)$ \\
\hline & {$[-2.31933]$} & {$[-1.98258]$} & {$[-0.44505]$} & [ 0.85990] & [-1.39211] \\
\hline \multirow[t]{3}{*}{$\mathrm{D}(\mathrm{YIND}(-1))$} & -0.24725 & -0.002609 & 0.007034 & 0.040236 & -0.22543 \\
\hline & $(0.17165)$ & $(0.02213)$ & $(0.04442)$ & $(0.02861)$ & $(0.18172)$ \\
\hline & {$[-1.44040]$} & {$[-0.11791]$} & [ 0.15837$]$ & [ 1.40642$]$ & {$[-1.24054]$} \\
\hline \multirow{3}{*}{$\mathrm{D}(\mathrm{YIND}(-2))$} & -0.104346 & 0.005980 & 0.029760 & 0.059756 & -0.051845 \\
\hline & $(0.16783)$ & $(0.02163)$ & $(0.04343)$ & $(0.02797)$ & $(0.17767)$ \\
\hline & {$[-0.62175]$} & {$[0.27645]$} & {$[0.68528]$} & [ 2.13634] & {$[-0.29181]$} \\
\hline \multirow{3}{*}{ D(LGDPIND(-1)) } & 0.405895 & -0.514957 & 0.420375 & 0.404468 & 0.145819 \\
\hline & (1.99630) & $(0.25731)$ & $(0.51656)$ & $(0.33272)$ & $(2.11336)$ \\
\hline & [ 0.20332] & {$[-2.00129]$} & [ 0.81379$]$ & [ 1.21564$]$ & {$[0.06900]$} \\
\hline \multirow[t]{3}{*}{ D(LGDPIND(-2)) } & 1.394227 & -0.424816 & 0.612340 & 0.175685 & -0.042358 \\
\hline & (1.98884) & $(0.25635)$ & $(0.51463)$ & $(0.33148)$ & $(2.10547)$ \\
\hline & {$[0.70102]$} & {$[-1.65716]$} & [ 1.18986$]$ & [ 0.53001$]$ & {$[-0.02012]$} \\
\hline \multirow[t]{3}{*}{$\mathrm{D}(\operatorname{LDIND}(-1))$} & -0.707054 & -0.027838 & -0.126654 & 0.112954 & -0.097358 \\
\hline & $(0.86062)$ & $(0.11093)$ & $(0.22269)$ & $(0.14344)$ & $(0.91109)$ \\
\hline & {$[-0.82156]$} & {$[-0.25095]$} & {$[-0.56874]$} & {$[0.78748]$} & {$[-0.10686]$} \\
\hline \multirow[t]{3}{*}{$\mathrm{D}(\operatorname{LDIND}(-2))$} & 0.167004 & -0.117548 & 0.125365 & 0.176921 & 0.190008 \\
\hline & $(0.94585)$ & $(0.12192)$ & $(0.24475)$ & $(0.15764)$ & $(1.00132)$ \\
\hline & {$[0.17656]$} & {$[-0.96418]$} & {$[0.51222]$} & [ 1.12229$]$ & {$[0.18976]$} \\
\hline \multirow[t]{3}{*}{$\mathrm{D}(\mathrm{LI}(-1))$} & -0.55302 & 0.326956 & 0.020763 & 0.227244 & -0.08134 \\
\hline & $(1.27007)$ & $(0.16370)$ & $(0.32864)$ & $(0.21168)$ & $(1.34454)$ \\
\hline & {$[-0.43543]$} & [ 1.99723] & [ 0.06318$]$ & [ 1.07353$]$ & {$[-0.06050]$} \\
\hline \multirow[t]{3}{*}{$\mathrm{D}(\mathrm{LI}(-2))$} & 2.329830 & 0.182872 & -0.256772 & 0.010555 & 1.732722 \\
\hline & $(1.25046)$ & $(0.16118)$ & $(0.32357)$ & $(0.20841)$ & $(1.32379)$ \\
\hline & [ 1.86317$]$ & [ 1.13460$]$ & {$[-0.79356]$} & {$[0.05065]$} & [ 1.30891$]$ \\
\hline \multirow[t]{3}{*}{ D(LBRENT(-1)) } & 0.384362 & 0.072556 & -0.082438 & 0.103718 & 0.460090 \\
\hline & $(0.19506)$ & $(0.02514)$ & $(0.05047)$ & $(0.03251)$ & $(0.20650)$ \\
\hline & [ 1.97046$]$ & [ 2.88577] & {$[-1.63327]$} & [ 3.19029] & [ 2.22804] \\
\hline \multirow[t]{3}{*}{ D(LBRENT(-2)) } & 0.329572 & 0.015240 & -0.058463 & -0.046036 & -0.180083 \\
\hline & $(0.20327)$ & $(0.02620)$ & $(0.05260)$ & $(0.03388)$ & $(0.21519)$ \\
\hline & [ 1.62134$]$ & [ 0.58168$]$ & {$[-1.11151]$} & {$[-1.35884]$} & {$[-0.83685]$} \\
\hline \multirow[t]{3}{*}{$\mathrm{C}$} & -0.007821 & 0.015891 & -0.013475 & -0.008732 & 0.035612 \\
\hline & $(0.03943)$ & $(0.00508)$ & $(0.01020)$ & $(0.00657)$ & $(0.04175)$ \\
\hline & {$[-0.19833]$} & [ 3.12646$]$ & {$[-1.32057]$} & {$[-1.32852]$} & {$[0.85306]$} \\
\hline R-squared & 0.355028 & 0.318013 & 0.326481 & 0.558376 & 0.311887 \\
\hline Adj. R-squared & 0.110383 & 0.059328 & 0.071008 & 0.390863 & 0.050879 \\
\hline Sum sq. resids & 0.758489 & 0.012601 & 0.050786 & 0.021069 & 0.850052 \\
\hline S.E. equation & 0.161724 & 0.020845 & 0.041848 & 0.026954 & 0.171208 \\
\hline F-statistic & 1.451198 & 1.229345 & 1.277946 & 3.333336 & 1.194932 \\
\hline Log likelihood & 23.61851 & 107.6176 & 79.04455 & 97.08029 & 21.28212 \\
\hline Akaike AIC & -0.566757 & -4.664273 & -3.270466 & -4.150258 & -0.452786 \\
\hline Schwarz SC & -0.065223 & -4.16274 & -2.768932 & -3.648725 & 0.048747 \\
\hline Mean dependent & 0.010988 & 0.008202 & -0.006593 & -0.005116 & 0.026942 \\
\hline S.D. dependent & 0.171464 & 0.021493 & 0.043418 & 0.034536 & 0.175737 \\
\hline \multicolumn{2}{|c|}{ Determinant resid covariance (dof adj.) } & $1.26 \mathrm{E}-13$ & & & \\
\hline
\end{tabular}




\begin{tabular}{lr}
\hline Determinant resid covariance & $2.22 \mathrm{E}-14$ \\
Log likelihood & 353.5715 \\
Akaike information criterion & -14.07666 \\
Schwarz criterion & -11.36002
\end{tabular}

\subsubsection{Model for the Global Economy}

The Johansen cointegration test applied to the macroeconomic index, the indebtedness, the stock market index, the real effective exchange rate and the oil price series show that there is one long-term relationship:

$$
y=-10,6723-1,1266 \text { LD-0,5886 Ltunix }+3,2069 \text { Lreer }+0,2403 \text { Lbrent }+\varepsilon_{t}
$$

$$
\text { [4.37947] [17.7094] [-6.38135] [-5.08733] }
$$

In the long-run, a 10 point increase in the reer causes an increase of 2,4 point increase of $y$ and then on the default rate. More, a 10 point increase in REER has a bigger effect of 32 point increase on $y$. While, an increase by 10 point of tunix diminishes the macroecomic index by 5,8 points, that means, the default rate will be better. But, contrarily to our hypothesis, indebtedness increase in the whole economy decreases the default rate level in the long-run.

In the second stage, the short-term relationships can be identified in an ECM model where the optimal lag length is 2 according to Akaike Information. The differenced ECM coefficient is negative and $<1$ in absolute value, then in case of disequilibrium in the short-run, the default rate returns quickly to its equilibrium path by just a $50 \%$ adjustment, or 6 months to return to equilibrium. We note also a unidirectional causality from key macroeconomic index y lagged one period to the stock market index in a negative manner.

\subsection{Policy Implications}

It's often difficult or impossible to foresee default rate in a developing country. That's why, we try to prevent default rate based on a macroeconomic credit risk model which can be used to perform the central bank analysis and policy in Tunisia. We applied separate models for global economy, estate, agriculture, industry, service and tourism relying on global and sectorial Non Performing Loans rate for the period 2000-2010. The findings uncover that the main drivers of credit risk are interest rate, specific indebtedness, oil price and real effective exchange rate. Following the 44 quarterly observations, it appears that the macroeconomic index and some macroeconomic variables were not found to be stationary separately, but when the analysis was conducted with these variables together, they were found to be cointegrated and they moved together in the long run. Then, it could be concluded that any changes for monetary policy will affect credit risk.

The results obtained suggest that there are long relationship at the global economy model and at each sector model, between the respective index and the Tunisian macroeconomic developments. Then, non-performing loans rates in Tunisian economy and its leading sectors are affected by macroeconomic variables in the long run. But, the variables involved differ according to the sector, which implies pursuing policy depending on the sector. Such that, the policy adopted on the agriculture default rate should proceed optimally on indebtedness in this sector, real effective exchange rate and interest rate. The estate sector model shows a cointegration vector between its sector index, its indebtedness, the short-run interest rate and the oil price. One possible policy suggestion knowing the negative relationship is to encourage granting loans for the estate corporate. The Johansen test indicates also a long-term relationship linking the non-performing rate in the service sector to the macroeconomic variables evolution of the interest rate and the oil price. We find cointegration relation in the tourism sector between the credit risk in this sector at one side and the tourism indebtedness, the interest rate and the oil price in the other side. It's recommended to review the indebtedness level reached for the service corporate. The industry sector shows also a long term relationship between the non-performing loans rate in this sector and its indebtedness, short term interest rate and the petroleum price. For the global economy model, the significative effect of global indebtedness, the stock market index, the real effective exchange rate and the oil price should be followed by monetary authority to prevent the total NPL rate.

The finding of cointegration or long-run equilibrium relationship among the variables used in the study is very important for the policy designers to provide a methodological and economic viewpoint. Therefore, policy makers should pay close attention to macroeconomic factors that positively affect credit risk.

\section{Discussion}

The aim of this paper was to provide a framework for assessing credit risk in Tunisian economy in terms of macroeconomic factors. The study applied macroeconomic credit risk modeling which can be used to perform 
the central bank analysis and its policy.

In the first step, separate models for global economy, estate, agriculture, industry, service and tourism sectors are constructed, relying on Non Performing Loans global rate and specific to each sector for the period 2000-2010 in quarter frequency.

Most of these series exhibit significant serial dependence and departures from normality and have unit roots.

The VECM methodology was chosen to examine this issue since it allows the identification of long-term relations of cointegration between the levels of non-stationary variables, taking into account the dynamic relationship between these variables.

The empirical results suggest that the main drivers of credit risk are indebtedness, real effective exchange rate and interest rate for agriculture sector; indebtedness, interest rate and oil price for estate sector; interest rate and oil price for service; indebtedness, interest rate and oil price for tourism; indebtedness, interest rate and oil price for industry; indebtedness, stock market return index, real effective exchange rate and Brent price for the whole economy.

The evidence of cointegration among these variables in the context of the whole Tunisian economy and five economic sectors such as agriculture, real estate, tourism, service and industry tends to suggest that these six macro-aggregates are bound together by long-term equilibrium relationship.

The findings for the study are mostly not consistent with the hypothesis in the long-term relationship. But, mostly consistent with the assumptions in a point of view of short-term relationship.

This finding of cointegration or long-run equilibrium relationship among all these variables is very important for the policy designers.

Therefore, monetary authorities should be careful in revision of interest rates as default rate responds to such decisions negatively in long-term and positively in short-run for the service, industry and estate sectors. Similarly, Tunisian Central Bank should also consider the impact of specific indebtedness on global and sectorial default rate as it has generally significant negative long-term relationship with the relative non-performing loans. The real effective exchange rate has with global non-performing rate a long-term relationship in a positive sense, then monetary authorities adopting flexible exchange rate should take into account this limit. Moreover, it appears that there is in one hand a negative cointegrating relationship among stock market index and global default rate and in the other hand, a positive one between the former variable and the oil price. Then, BCT should care of the tunix and the oil price evolution to prevent creditors reaction in the long-term.

Data limitations are the main restriction of the study. More, Error Correction Model methodology is sensitive to the choice of lag lengths. The ADF tests are sensitive too to the specification of the variables and the lag lengths used. But, it should be reminded that VECM yields more efficient estimators of cointegrating vectors.

Useful future contributions to the subject matter of this paper arise from the recent financial crisis in the form of several challenges facing macroeconomics and policy. Amongst the challenges are stress-tesing of macroeconomic models, improving our evaluation of various scenarios of macro-financial linkages and developing tools for macroprudential regulation. In fact, integrating these issues is at the leading edge of research in the area of integrating finance and macroeconomics.

\section{References}

Allen, L., \& Saunders, A. (2004). Incorporating systemic influences into risk measurements: A survey of the literature. Journal of Financial Services Research, 26, 161-191. http://dx.doi.org/10.1023/B:FINA.0000037545.38154.8a

Asghar, A., \& Kevin, D. (2010). Macroeconomic determinants of credit risk: Recent evidence from a cross country study. International Review of Financial Analysis, 19, 165-171. http://dx.doi.org/10.1016/j.irfa.2010.03.001

Bangia, A., Diebold, F., Kronimus, A., Schagen, C., \& Schuerman, T. (2002). Ratings migration and the business cycle with applications to credit portfolio stress testing. Journal of Banking and Finance, 26, 235-264. http://dx.doi.org/10.1016/S0378-4266(01)00229-1

Borio, C., \& Lowe, P. (2002). Assessing the risk of banking crises. BIS Quarterly Review.

Boss, M. (2002). A macroeconomic credit risk model for stress testing the Austrian credit portfolio. Financial Stability Report, 4, 64-82.

Boss, M., Breuer, T., Elsinger, H., Krenn, G., Lehar, A., Puhr, C., \& Summer, M. (2006). Systemic risk monitor: 
A model for systemic risk analysis and stress testing of banking systems. Internal Technical Document, Oesterreichische Nationalbank.

Carling, K., Tor, J., Lind'e, J., \& Kasper, R. (2007). Corporate credit risk modeling and the macroeconomy. Journal of Banking and Finance, 31(3), 845-868. http://dx.doi.org/10.1016/j.jbankfin.2006.06.012

Davis, E. P., \& Karim, D. (2008). Comparing early warning systems for banking crises. Journal of Financial Stability, 4, 89-120. http://dx.doi.org/10.1016/j.jfs.2007.12.004

Demirgüç-Kunt, A., \& Detragiache, E. (2005). Cross-country empirical studies of systemic bank distress: A survey. IMF Working paper 05/96.

Dimitrios, P., Louzis, A., Vouldis, T., \& Vasilios, L. M. (2012). Macroeconomic and bank-specific determinants of non-performing loans in Greece: A comparative study of mortgage, business and consumer loan portfolios. Journal of Banking \& Finance, 36(4), $1012-1027$. http://dx.doi.org/10.1016/j.jbankfin.2011.10.012

Duffie, D., Leandro, S., \& Wang, K. (2007). Multi-period corporate default prediction with stochastic covariates. Journal of Financial Economics, 83, 635-665. http://dx.doi.org/10.1016/j.jfineco.2005.10.011

Figlewski, S. (2012). Modeling the effect of macroeconomic factors on corporate default and credit rating transitions. International Review of Economics \& Finance, 21(1), 87-105. http://dx.doi.org/10.1016/j.iref.2011.05.004

Fofack, H. (2005). Nonperforming loans in Sub-Saharan Africa: Causal analysis and macroeconomic implications. World Bank Policy Research Working Paper 3769.

Gray, D., \& Walsh, J. P. (2008). Factor model for stress-testing with a contingent claims model of the Chilean banking system. IMF Working Paper 89.

Jakubík, P. (2007). Macroeconomic environment and credit risk. Czech Journal of Economics and Finance, $57(2), 60-78$.

Jakubik, P., \& Schmieder, C. (2008). Stress testing credit risk: Comparison of the Czech Republic and Germany, Financial Stability Institute. Bank for International Settlements, FSI Award 2008 Winning Paper.

Jarrow, R. A., \& Turnbull, S. (1995). Pricing options on financial securities subject to default risk. Journal of Finance, 50, 53-86. http://dx.doi.org/10.1111/j.1540-6261.1995.tb05167.x

Jarrow, R. A., Lando, D., \& Turnbull, S. (1997). A Markov model for the term structure of credit risk spreads. Review of Financial Studies, 10, 481-523. http://dx.doi.org/10.1093/rfs/10.2.481

Johansen, S. (1988). Statistical analysis of cointegration vectors. Journal of Economic Dynamics and Control, 12 , 231-254. http://dx.doi.org/10.1016/0165-1889(88)90041-3

Johansen, S., \& Juselius, K. (1990). Maximum likelihood estimation and inference on cointegration-With applications to the demand for money. Oxford Bulletin of Economics and Statistics, 52, 169-210. 10.1111/j.1468-0084.1990.mp52002003.x

Kalirai, H., \& Scheicher, M. (2002). Macroeconomic stress testing: Preliminary evidence for Austria. Financial Stability Report, 3, 58-74.

Koopman, S. J., \& Lucas, A. (2005). Business and default cycles for credit risk. Journal of Applied Econometrics, 20(2), 311-23. http://dx.doi.org/10.1002/jae.833

Koopman, S., Andr'e, L., \& Andr'e, M. (2008). The multi-state latent factor intensity model for credit rating transitions. Journal of Econometrics, 142, 399-424. http://dx.doi.org/10.1016/j.jeconom.2007.07.001

Lando, D., \& Torben, S. (2002). Analyzing ratings transitions and rating drift with continuous observations. Journal of Banking \& Finance, 26(2-3), 423-444. http://dx.doi.org/10.1016/S0378-4266(01)00228-X

Nickell, P., William, P., \& Varotto, S. (2000). Stability of rating transitions. Journal of Banking \& Finance, 24(12), 203-222. http://dx.doi.org/10.1016/S0378-4266(99)00057-6

Pesaran, M. H., Pettenuzzo, D., \& Timmermann, A. (2006). Forecasting time series subject to multiple structural breaks. Review of Economic Studies, 73, 1057-1084. http://dx.doi.org/10.1111/j.1467-937X.2006.00408.x

Salas, V., \& Saurina, J. (2002). Credit risk in two institutional regimes: Spanish commercial and savings banks. Journal of Financial Services Research, 22, 203-224. http://dx.doi.org/10.1023/A:1019781109676

Tabak et al. (2011). Modeling default probabilities: The case of Brazil. Journal of International Financial 
Markets, Institutions and Money, 21(4), 513-534. http://dx.doi.org/10.1016/j.intfin.2011.01.007

Virolainen, K. (2004). Macro stress testing with a macroeconomic credit risk model for Finland. Bank of Finland, Discussion Paper, no. 18.

Wilson, T. C. (1997a). Portfolio credit risk (I). Risk, 10(9), 111-117.

Wilson, T. C. (1997b). Portfolio credit risk (II). Risk, 10(10), 56-61.

\section{Note}

Note 1. We use here $\left(-y_{t}\right)$ instead of $\left(y_{t}\right)$ as the original wilson's model to have $\left(y_{t}\right)$ and $\left(p_{t}\right)$ positively correlated.

\section{Copyrights}

Copyright for this article is retained by the author(s), with first publication rights granted to the journal.

This is an open-access article distributed under the terms and conditions of the Creative Commons Attribution license (http://creativecommons.org/licenses/by/3.0/). 